This is an electronic reprint of the original article. This reprint may differ from the original in pagination and typographic detail.

\author{
Author(s): Kilpi, Lauri; Ylivaara, Oili M. E.; Vaajoki, Antti; Malm, Jari; Sintonen, Sakari; Tuominen, \\ Marko; Puurunen, Riikka L.; Ronkainen, Helena
}

Title: $\quad$ Microscratch testing method for systematic evaluation of the adhesion of atomic layer deposited thin films on silicon

Year: $\quad 2016$

Version:

Please cite the original version:

Kilpi, L., Ylivaara, O. M. E., Vaajoki, A., Malm, J., Sintonen, S., Tuominen, M., Puurunen, R. L., \& Ronkainen, H. (2016). Microscratch testing method for systematic evaluation of the adhesion of atomic layer deposited thin films on silicon. Journal of Vacuum Science and Technology A, 34(1), Article 01A124.

https://doi.org/10.1116/1.4935959

All material supplied via JYX is protected by copyright and other intellectual property rights, and duplication or sale of all or part of any of the repository collections is not permitted, except that material may be duplicated by you for your research use or educational purposes in electronic or print form. You must obtain permission for any other use. Electronic or print copies may not be offered, whether for sale or otherwise to anyone who is not an authorised user. 


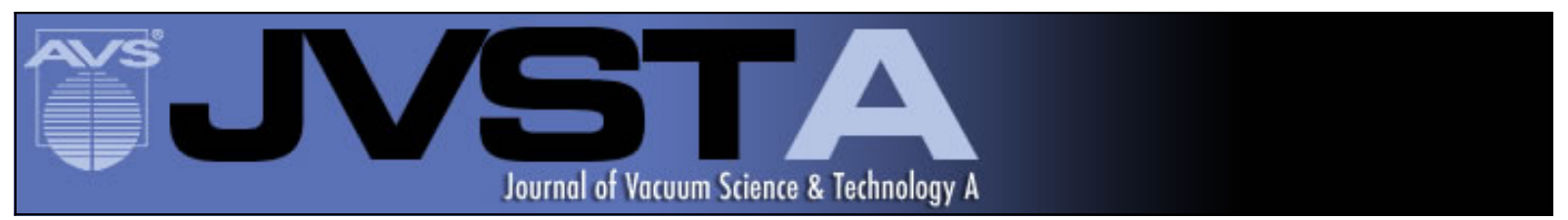

\section{Microscratch testing method for systematic evaluation of the adhesion of atomic layer deposited thin films on silicon}

Lauri Kilpi, Oili M. E. Ylivaara, Antti Vaajoki, Jari Malm, Sakari Sintonen, Marko Tuominen, Riikka L. Puurunen, and Helena Ronkainen

Citation: Journal of Vacuum Science \& Technology A 34, 01A124 (2016); doi: 10.1116/1.4935959

View online: http://dx.doi.org/10.1116/1.4935959

View Table of Contents: http://scitation.aip.org/content/avs/journal/jvsta/34/1?ver=pdfcov

Published by the AVS: Science \& Technology of Materials, Interfaces, and Processing

\section{Articles you may be interested in}

Adhesion testing of atomic layer deposited $\mathrm{TiO} 2$ on glass substrate by the use of embedded $\mathrm{SiO} 2$ microspheres J. Vac. Sci. Technol. A 32, 01 A102 (2014); 10.1116/1.4827197

Atomic layer deposition onto carbon fiber: From single layer deposition via multilayer structure to metal oxide microtubes

J. Vac. Sci. Technol. A 31, 01A139 (2013); 10.1116/1.4768917

Optical properties of cobalt slanted columnar thin films passivated by atomic layer deposition

Appl. Phys. Lett. 100, 011912 (2012); 10.1063/1.3675549

Electrical characteristics of Ga 203 - TiO 2 nanomixed films grown by plasma-enhanced atomic-layer deposition for gate dielectric applications

Appl. Phys. Lett. 87, 082909 (2005); 10.1063/1.2034100

High dielectric constant TiO 2 thin films on a Ru electrode grown at $250^{\circ} \mathrm{C}$ by atomic-layer deposition

Appl. Phys. Lett. 85, 4112 (2004); 10.1063/1.1812832

\section{HDDEN}

\section{Instruments for Advanced Science}

Contact Hiden Analytical for further details: w www.HidenAnalytical.com E info@hiden.co.uk CLICK TO VIEW our product catalogue

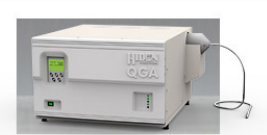

Gas Analysis

, dynamic measurement of reaction gas streams catalysis and thermal analysis , cataysis and thermal analy ', molecular beam studies

, fermentation, environmental and ecological studies

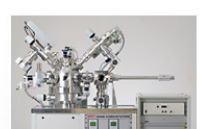

Surface Science

UHVTPD

SIMS emental imaging - surface mapping

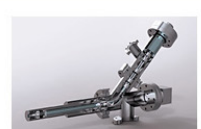

Plasma Diagnostics plasma source characterization etch and deposition process reaction kinetic studies ,analysis of neutral and radical species

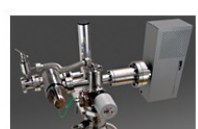

Vacuum Analysis ? partial pressure measurement and control of process gases reactive sputter process control vacuum diagnostics vacuum coating process monitoring 


\title{
Microscratch testing method for systematic evaluation of the adhesion of atomic layer deposited thin films on silicon
}

\author{
Lauri Kilpi, ${ }^{\text {a) }}$ Oili M. E. Ylivaara, and Antti Vaajoki \\ VTT Technical Research Centre of Finland Ltd., P.O. Box 1000, FI-02044 VTT, Finland \\ Jari Malm \\ Department of Physics, University of Jyväskylä, P.O. Box 35, Jyväskylä 40014, Finland \\ Sakari Sintonen \\ Department of Micro- and Nanosciences, Aalto University School of Electrical Engineering, P.O. Box 13500, \\ FI-00076 AALTO, Finland \\ Marko Tuominen \\ ASM Microchemistry Oy, Pietari Kalmin katu 1 F 2, FIN-00560 Helsinki, Finland \\ Riikka L. Puurunen and Helena Ronkainen \\ VTT Technical Research Centre of Finland Ltd., P.O. Box 1000, FI-02044 VTT, Finland
}

(Received 1 September 2015; accepted 2 November 2015; published 20 November 2015)

\begin{abstract}
The scratch test method is widely used for adhesion evaluation of thin films and coatings. Usual critical load criteria designed for scratch testing of coatings were not applicable to thin atomic layer deposition (ALD) films on silicon wafers. Thus, the bases for critical load evaluation were established and the critical loads suitable for ALD coating adhesion evaluation on silicon wafers were determined in this paper as $\mathrm{L}_{\mathrm{CSi} 1}, \mathrm{~L}_{\mathrm{CSi}}, \mathrm{L}_{\mathrm{CALD} 1}$, and $\mathrm{L}_{\mathrm{CALD} 2}$, representing the failure points of the silicon substrate and the coating delamination points of the ALD coating. The adhesion performance of the $\mathrm{ALD} \mathrm{Al}_{2} \mathrm{O}_{3}, \mathrm{TiO}_{2}$, TiN, and $\mathrm{TaCN}+\mathrm{Ru}$ coatings with a thickness range between 20 and $600 \mathrm{~nm}$ and deposition temperature between 30 and $410^{\circ} \mathrm{C}$ on silicon wafers was investigated. In addition, the impact of the annealing process after deposition on adhesion was evaluated for selected cases. The tests carried out using scratch and Scotch tape test showed that the coating deposition and annealing temperature, thickness of the coating, and surface pretreatments of the Si wafer had an impact on the adhesion performance of the ALD coatings on the silicon wafer. There was also an improved load carrying capacity due to $\mathrm{Al}_{2} \mathrm{O}_{3}$, the magnitude of which depended on the coating thickness and the deposition temperature. The tape tests were carried out for selected coatings as a comparison. The results show that the scratch test is a useful and applicable tool for adhesion evaluation of ALD coatings, even when carried out for thin $(20 \mathrm{~nm}$ thick) coatings. ( 2015 American Vacuum Society. [http://dx.doi.org/10.1116/1.4935959]
\end{abstract}

\section{INTRODUCTION}

Atomic layer deposition (ALD) is a chemical vapor deposition (CVD) method that allows deposition of uniform coatings on complicated 3D geometries. The ALD technique is based on sequential gas-solid reactions that are selfterminating. ALD operates by exposing a solid surface alternately to reactive gaseous chemicals, the exposures being separated by purge/evacuation. ${ }^{1-3}$

One of the main motivations for the recent development of ALD has been semiconductor processing. Miniaturization in the semiconductor industry has led to the requirement for atomic level control of thin film deposition. ${ }^{3}$ The films deposited by ALD can also be utilized in microelectromechanical systems (MEMS). ${ }^{4,5}$ The major benefit of ALD for MEMS is the combination of low deposition temperatures (often below $300^{\circ} \mathrm{C}$ ) with conformal coatings-the combination not achieved by conventional fabrication technologies. ${ }^{5,6}$ From the early 2000s, the reports of ALD for MEMS deal with ALD as a tribological coating ${ }^{7}$ and an insulator

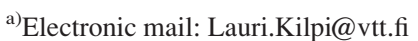

layer. ${ }^{8}$ Since then, ALD films have been demonstrated, e.g., as dielectric layers in RF-MEMS,${ }^{9}$ lubricating films, ${ }^{10}$ insulator in MEMS compass, ${ }^{11,12}$ mirrors in Fabry-Perot interferometers for visible light, ${ }^{13,14}$ antistiction layers, ${ }^{15}$ and nanoelectromechanical system switches. ${ }^{16}$

The performance and reliability of MEMS devices can be dominated by interfacial phenomena such as adhesion, friction, and wear. ${ }^{7}$ Adhesion failure is often the primary failure mechanism of the coating, limiting its applicability and lifetime. Therefore, the adhesion to the substrate is one of the most important functional requirements for the coatings. ${ }^{17}$ The adhesion of ALD films is most often evaluated using Scotch tape testing where a tape is pressed onto the film and rapidly stripped. ${ }^{18}$ This method is highly qualitative, dependent on user behavior. The method mainly distinguishes whether the tested coating has poor adhesion properties or not. For these reasons, a more controlled and quantitative method is needed. Scratch testing is a widely used alternative to get quantitative information about the adhesion behavior of the coatings ${ }^{19}$ and has been recently utilized for ALD coatings. ${ }^{20-23}$

In a typical scratch testing setup, a diamond stylus is drawn against the coating-substrate system with an 
increasing load until the coating is removed from the substrate or some other failure occurs. The load generating the failure is determined as the critical load. The failure type in scratch testing depends on several factors, such as the test load, coating thickness, residual stress in the coating, properties of the substrate and coating, indenter radius, loading rate, and sliding speed. ${ }^{24}$ For thin and hard coatings, the indenter tip has to be sufficiently large to induce an adequate stress field to cause an adhesion failure. If the tip is too sharp, the induced stress field might be bending, which, if high enough, leads to cohesive failure of the coating. ${ }^{25} \mathrm{In}$ the scratch testing of hard coatings, there are two adhesion related failure modes: wedge spallation and buckling. ${ }^{26}$ Buckling occurs for thin coatings which are able to bend in response to applied stress whereas wedge spallation happens usually for thicker (over $10 \mu \mathrm{m}$ ) coatings. ${ }^{26}$ Comparisons between different samples using scratch testing are only valid if the failure mechanism is the same in all samples. ${ }^{24}$

In this study, critical load criteria developed for ALD films were used to describe the effect of deposition temperature, film thickness, and annealing temperature on the adhesion performance of aluminum oxide $\left(\mathrm{Al}_{2} \mathrm{O}_{3}\right)$, titanium oxide $\left(\mathrm{TiO}_{2}\right)$, titanium nitride (TiN), and tantalum carbonitride + ruthenium $(\mathrm{TaCN}+\mathrm{Ru})$ coatings. Also, the influence of cleaning procedures on coating adhesion was evaluated. For comparison, Scotch tape tests were carried out.

\section{EXPERIMENT}

\section{A. ALD coating preparation}

Single and double sided polished $150 \mathrm{~mm}$ p-type $\langle 100\rangle$ silicon wafers with thicknesses of 380 and $675 \mu \mathrm{m}$ were used as substrates. Wafers were cleaned before the ALD using standard Radio Corporation of America (RCA) cleaning baths (SC1, HF, and SC2) ${ }^{27}$ as described in previous work. ${ }^{21}$ For selected wafers, the influence of substrate pretreatment to adhesion was studied by cleaning wafers with $\mathrm{SC} 1+\mathrm{HF}$ [ $\left.\mathrm{H}_{2} \mathrm{O}: \mathrm{HF}(50 \%) 50: 1\right]$ prior to ALD.

Aluminum oxide $\left(\mathrm{Al}_{2} \mathrm{O}_{3}\right)$ and titanium dioxide $\left(\mathrm{TiO}_{2}\right)$ were grown in a top-flow Picosun ${ }^{\mathrm{TM}} \mathrm{R}-150$ ALD reactor. Precursors were trimethylaluminum $\left(\mathrm{Me}_{3} \mathrm{Al}\right)$, titanium tetrachloride $\left(\mathrm{TiCl}_{4}\right)$ and water $\left(\mathrm{H}_{2} \mathrm{O}\right)$. The intermediate space pressure was about $7 \mathrm{hPa}$, and nitrogen (purity $>99.999 \%$ ) was used both as a purge gas and for flushing the reactant lines with a constant $200 \mathrm{sccm}$ flow. Electronic grade $\mathrm{Me}_{3} \mathrm{Al}$ and $\mathrm{TiCl}_{4}$ precursors were from SAFC Hitech. $\mathrm{Me}_{3} \mathrm{Al}$ and $\mathrm{TiCl}_{4}$ precursors were cooled with a Peltier element to about 17 and $14^{\circ} \mathrm{C}$, respectively. Water was used at room temperature without cooling. Precursor dose and purge times were 0.1 and $4.0 \mathrm{~s}$, respectively, for $\mathrm{Me}_{3} \mathrm{Al}, \mathrm{TiCl}_{4}$, and $\mathrm{H}_{2} \mathrm{O}$. Samples were grown at a temperature range from 110 to $300^{\circ} \mathrm{C}$ using 0.1-4.0, 0.1-4.0, and 0.1-4.0 s for $\mathrm{Me}_{3} \mathrm{Al}, \mathrm{TiCl}_{4}$, and $\mathrm{H}_{2} \mathrm{O}$ pulse-purge sequences, respectively. For $\mathrm{Al}_{2} \mathrm{O}_{3}$ grown at $300{ }^{\circ} \mathrm{C}$ pulse sequence for $\mathrm{Me}_{3} \mathrm{Al}$ and $\mathrm{H}_{2} \mathrm{O}$, pulse-purge was $0.1-1.0$ and $0.1-1.0 \mathrm{~s}$. The layer thicknesses were varied from 20 to $600 \mathrm{~nm}$ for $\mathrm{Al}_{2} \mathrm{O}_{3}$ and from 25 to $300 \mathrm{~nm}$ for $\mathrm{TiO}_{2}$.

ALD $\mathrm{Al}_{2} \mathrm{O}_{3}$ films for low temperature experiments were deposited in a Beneq TFS 200 ALD reactor at 1.5 mbar pressure and in the temperature range of $30-110^{\circ} \mathrm{C}$. Precursors $\left(\mathrm{Me}_{3} \mathrm{Al}\right.$ and $\left.\mathrm{H}_{2} \mathrm{O}\right)$ were evaporated by means of their own vapor pressure from external precursor bottles kept at $20^{\circ} \mathrm{C}$. Electronic grade $\mathrm{Me}_{3} \mathrm{Al}$ precursor was from SAFC Hitech. Nitrogen was used as the purge gas and it was generated from compressed particle-free dry air by an Inmatec PN-1150 molecular sieve nitrogen separator (purity $>99.999 \%$ ). The precursor pulses were kept at $0.15 \mathrm{~s}$ and the purge periods following the $\mathrm{Me}_{3} \mathrm{Al} / \mathrm{H}_{2} \mathrm{O}$ precursor pulses were varied with deposition temperature, being 10/30, $7 / 20,5 / 10,4 / 5$, and $2 / 3 \mathrm{~s}$ for samples deposited at $30,50,70$, 90 , and $110^{\circ} \mathrm{C}$, respectively. Hence, for example, the pulse sequence for the sample deposited at $110^{\circ} \mathrm{C}$ was $0.15-2.0$ and $0.15-3.0 \mathrm{~s}$. The number of deposition cycles was also varied with temperature to aim at a $100 \mathrm{~nm}$ film thickness.

The influence of the post-ALD annealing to adhesion was tested with selected wafers. Prior to the ALD, the wafers were annealed at $950{ }^{\circ} \mathrm{C}$ for $30 \mathrm{~min}$ in an $\mathrm{N}_{2}$ atmosphere. The purpose was to prevent the formation of blisters ${ }^{28,29}$ in the $\mathrm{Al}_{2} \mathrm{O}_{3}$ grown wafers during the annealing at temperatures larger than $550^{\circ} \mathrm{C}$. Selected samples were then post-ALD annealed at $300,450,700$, and $900^{\circ} \mathrm{C}$ for $30 \mathrm{~min}$ using $1 \mathrm{slm}$ nitrogen flow. Annealing was carried out using annealing furnace PEO-603.

The ALD TiN films were deposited in ASM's Pulsar ${ }^{\circledR}$ 2000 cross-flow single-wafer ALD reactor using $\mathrm{TiCl}_{4}$ (Sigma-Aldrich 99.9\%) and $\mathrm{NH}_{3}$ (AGA 5.0 with purifier) as precursors and nitrogen (AGA High Tech with purifier) as carrier and purge gas. The precursors were kept at room temperature of about $21^{\circ} \mathrm{C}$.

The ALD TaCN films were deposited in ASM's Pulsar ${ }^{\circledR}$ 3000 cross-flow single-wafer ALD reactor using $\mathrm{TaF}_{5}$ (ABCR 99.5\%) and tetramethyldisilazane (TMDS) (ABCR 97\%) as precursors and nitrogen (AGA High Tech with purifier) as carrier and purge gas. The $\mathrm{TaF}_{5}$ source temperature was $90^{\circ} \mathrm{C}$, and TMDS was kept at room temperature of about $21^{\circ} \mathrm{C}$.

The ALD Ru films were deposited in ASM's Pulsar ${ }^{\circledR}$ 2000 cross-flow single-wafer ALD reactor using $\mathrm{Ru}(\mathrm{EtCp})_{2}$ (Praxair 99.9\%) and $\mathrm{O}_{2}$ (AGA Scientific Oxygen 6.0) as precursors and nitrogen (AGA High Tech with purifier) as carrier and purge gas. The $\mathrm{Ru}(\mathrm{EtCp})_{2}$ source temperature was $75^{\circ} \mathrm{C}$ and $\mathrm{O}_{2}$ was kept at room temperature of about $21^{\circ} \mathrm{C}$.

\section{B. X-ray reflectivity}

The thickness values of the ALD films were determined by $\mathrm{x}$-ray reflectivity (XRR). ${ }^{30,31}$ In XRR, x-rays are specularly reflected from interfaces of materials with different electron densities, and the influence of layer thicknesses on the reflected X-ray intensity may be recursively calculated as a function of scattering angle. ${ }^{32}$ The XRR measurements were performed under parallel beam conditions using a Philips X'Pert Pro diffractometer. The acceleration voltage, anode current, and x-ray wavelength were $40 \mathrm{kV}, 40 \mathrm{~mA}$, and $\mathrm{Cu}-\mathrm{K}_{\alpha}$, respectively. The film thickness values were obtained through simulation of XRR measurement curves using the software X'Pert Reflectivity. 


\section{Adhesion testing}

\section{Scratch testing}

Scratch testing was carried out with Anton Paar Tritec's Micro-Combi Tester. In the scratch test, a diamond tip generates a scratch on the coated surface with either constant or progressive load. During the scratch testing, the normal force, tangential force, friction coefficient, acoustic emission, and penetration depth are measured continuously. After scratching, the residual depth along the scratch channel is measured, and the scratch channel is investigated by the means of optical microscopy. The critical values can be defined according to the crack generation and delamination of the coating as described in the standard. ${ }^{33}$ However, the definition of critical loads typically used for physical vapor deposited and CVD coatings were not applicable for the thin ALD films deposited on silicon wafers. The reasons for this are as follows: first, the standard used for scratch testing is designed for thicker coatings than typical ALD coatings; second, there is a phase transformation ${ }^{34,35}$ that takes place while the silicon substrate is under a certain amount of stress and the substrate suddenly collapses. Therefore, a new way for adhesion evaluation of ALD layers deposited on silicon was developed. Four critical loads were determined based on the investigation of different types of ALD films. The critical load values were $\mathrm{L}_{\mathrm{CSi} 1}$ and $\mathrm{L}_{\mathrm{CSi} 2}$ for the failure occurring in silicon substrate, and $\mathrm{L}_{\mathrm{CALD} 1}$ and $\mathrm{L}_{\mathrm{CALD} 2}$ for the delamination failures for the coating.

In this study, the same diamond tip with the radius of $20 \mu \mathrm{m}$ was used in testing. The tip was cleaned with ethanol and tissue wiper in the beginning of the measurements and when changing sample. The samples investigated are presented in Table I. The coated samples were glued on aluminum disks ( $\mathrm{Al} \mathrm{6082)}$ of $10 \mathrm{~mm}$ thickness and $40 \mathrm{~mm}$ diameter to attach the sample to the Micro-Combi tester sample holder. The adhesive used was Henkel's Loctite 401. Different glues were compared and the one that provided the most stable performance with no effects on the silicon system under increasing load was selected. The normal force in scratch testing was continuously increasing from 0.05 to $1.3 \mathrm{~N}$. The maximum load was restricted to $1.3 \mathrm{~N}$ because the silicon substrate cracked heavily with higher loads. The scratch length was $3 \mathrm{~mm}$, and the scratching speed was $10 \mathrm{~mm} / \mathrm{min}$. At least three scratches were carried out per sample with the scratches being $0.5 \mathrm{~mm}$ apart from each other. The experiments were carried out in controlled temperature and humidity $\left(22 \pm 1{ }^{\circ} \mathrm{C}\right.$ and $50 \% \pm 5 \%$ relative humidity). After scratching, a panorama image of the scratch channel was taken, and optical microscope $(\mathrm{OM})$ was used to investigate the samples and to determine the critical loads. The selected samples were also analyzed by using the scanning electron microscope with an energy-dispersive x-ray spectrometer (FEI XL 30 ESEM). Energy-dispersive $\mathrm{x}$-ray spectroscopy analysis was carried out with a $15 \mathrm{kV}$ accelerating voltage.

\section{Tape testing}

In comparison, the adhesion performance was also evaluated by the Scotch tape testing for five samples with different cleaning and annealing processes (see Tables II and III). Testing was carried out using Scotch 3M 810 tape. In the test, the fresh tape surface was pressed against the surface with a finger using a similar force in a similar manner in all cases. The tape was pressed on the coating surface on an approximately $5 \times 20 \mathrm{~mm}$ area and after $30 \mathrm{~s}$ rapidly pulled off. The pulling was carried out in about $90^{\circ}$ angle to the coating surface. Afterwards, an optical microscope examination was carried out to observe possible coating delamination from the coated surface.

\section{RESULTS}

\section{A. Method for determining critical loads of ALD films on silicon}

The scratch testing was carried out to evaluate the adhesion performance of the ALD coatings. Four critical loads were determined to describe the failure mechanisms of the coating and the silicon substrate, namely, $\mathrm{L}_{\mathrm{CSi} 1}, \mathrm{~L}_{\mathrm{CSi} 2}$, $\mathrm{L}_{\mathrm{CALD} 1}$, and $\mathrm{L}_{\mathrm{CALD} 2}$.

The first critical load related to silicon substrate, $\mathrm{L}_{\mathrm{CSi}}$, was the first observed local breakage point of the silicon substrate, as shown in Fig. 1(a). The $\mathrm{L}_{\mathrm{CSi}}$ occurred for some cases as an early local crack generation in silicon causing the

TABLE I. Coatings evaluated in the adhesion experiments with the information on the deposition temperature, targeted coating thickness, and annealing temperatures. RCA-clean was used for the samples unless mentioned otherwise.

\begin{tabular}{|c|c|c|c|c|}
\hline Material & Series & Deposition $\mathrm{T}\left({ }^{\circ} \mathrm{C}\right)$ & Target thickness (nm) & Annealing $\mathrm{T}\left({ }^{\circ} \mathrm{C}\right)$ \\
\hline $\mathrm{Si}$ & Reference & & N.A. & - \\
\hline \multirow[t]{5}{*}{$\mathrm{Al}_{2} \mathrm{O}_{3}$} & Thickness & 300 & $20,50,100,300,600$ & - \\
\hline & Low temperature & $30,50,70,90,110$ & 100 & - \\
\hline & Temperature & $110,150,200,250,300$ & 300 & - \\
\hline & Post-ALD annealing & $110,200,300$ & 100 & $300,450,700,900$ \\
\hline & $\mathrm{SC} 1+\mathrm{HF}$ cleaning & 300 & 300 & - \\
\hline \multirow[t]{3}{*}{$\mathrm{TiO}_{2}$} & Thickness & 300 & $25,50,100$ & - \\
\hline & Temperature & $110,150,200,250,300$ & 100 & - \\
\hline & Post-ALD annealing & 110,300 & 100 & $300,450,900$ \\
\hline \multirow[t]{2}{*}{ TiN } & Thickness & 350 & $20,50,100$ & - \\
\hline & Temperature & $300,350,410$ & 100 & - \\
\hline $\mathrm{TaCN}+\mathrm{Ru}$ & Thickness & 300 & $(1+) 20,50,100$ & - \\
\hline
\end{tabular}


TABLE II. Critical load values with standard deviations for $\mathrm{Al}_{2} \mathrm{O}_{3}$ coated systems with different coating thicknesses, deposition parameters, and postannealing temperatures. The RCA-cleaning was used prior to deposition, except for the $\mathrm{SC} 1+\mathrm{HF}$ cleaned sample.

\begin{tabular}{|c|c|c|c|c|c|c|c|c|c|}
\hline Series & $\begin{array}{c}\text { Thickness } \\
(\mathrm{nm})\end{array}$ & $\begin{array}{l}\text { ALD } \\
\text { cycles }\end{array}$ & $\begin{array}{c}\text { Growth T } \\
\left({ }^{\circ} \mathrm{C}\right)\end{array}$ & $\begin{array}{c}\text { Annealing T } \\
\left({ }^{\circ} \mathrm{C}\right)\end{array}$ & $\begin{array}{l}\mathrm{L}_{\mathrm{CSi} 1} \\
(\mathrm{mN})\end{array}$ & $\begin{array}{l}\mathrm{L}_{\mathrm{CSi} 2} \\
(\mathrm{mN})\end{array}$ & $\begin{array}{c}\mathrm{L}_{\mathrm{CALD} 1} \\
(\mathrm{mN})\end{array}$ & $\begin{array}{c}\mathrm{L}_{\text {CALD2 }} \\
(\mathrm{mN})\end{array}$ & Tape test \\
\hline Si (Ref. 1) & - & - & - & - & $493 \pm 81$ & $727 \pm 69$ & - & - & - \\
\hline Si (Ref. 2) & - & - & - & - & $471 \pm 15$ & $716 \pm 63$ & - & - & - \\
\hline Thickness & 19.5 & 200 & 300 & - & $514 \pm 65$ & $649 \pm 24$ & $1048 \pm 65$ & $1048 \pm 65$ & - \\
\hline Thickness & 48.5 & 500 & 300 & - & $374 \pm 5$ & $612 \pm 2$ & $1027 \pm 27$ & $1126 \pm 19$ & - \\
\hline Thickness & 96.1 & 1000 & 300 & - & $627 \pm 20$ & $649 \pm 23$ & $1003 \pm 29$ & $1089 \pm 7$ & - \\
\hline Thickness, temperature and cleaning & 283.7 & 3000 & 300 & - & - & $1032 \pm 7$ & $1049 \pm 16$ & $1057 \pm 6$ & Pass $(3 / 3)$ \\
\hline Thickness & 566.9 & 6000 & 300 & - & - & $1094 \pm 1$ & $1109 \pm 1$ & $1109 \pm 1$ & - \\
\hline Low temperature & 99.5 & 1316 & 30 & - & - & $913 \pm 26$ & $913 \pm 26$ & $913 \pm 26$ & - \\
\hline Low temperature & 100.0 & 1266 & 50 & - & - & $844 \pm 19$ & $1020 \pm 32$ & $1149 \pm 44$ & - \\
\hline Low temperature & 100.0 & 1205 & 70 & - & - & $854 \pm 3$ & $1029 \pm 13$ & $1179 \pm 34$ & - \\
\hline Low temperature & 99.0 & 1149 & 90 & - & - & $822 \pm 12$ & $1031 \pm 39$ & $1143 \pm 30$ & - \\
\hline Low temperature & 99.4 & 1087 & 110 & - & - & $836 \pm 3$ & $977 \pm 90$ & $1131 \pm 22$ & - \\
\hline Low temperature & 94.4 & 1283 & 110 & - & - & $777 \pm 23$ & $828 \pm 9$ & $1105 \pm 16$ & - \\
\hline Temperature & 288.3 & 3933 & 110 & - & - & $1066 \pm 2$ & $1070 \pm 5$ & $1070 \pm 5$ & - \\
\hline Temperature & 285.4 & 3411 & 150 & - & - & $1087 \pm 3$ & $1097 \pm 1$ & $1108 \pm 5$ & - \\
\hline Temperature & 286.7 & 3120 & 200 & - & - & $1048 \pm 9$ & $1052 \pm 8$ & $1073 \pm 12$ & - \\
\hline Temperature & 291.9 & 3115 & 250 & - & - & $1056 \pm 5$ & $1062 \pm 8$ & $1106 \pm 10$ & - \\
\hline Anneal & 92.4 & 1283 & 110 & 300 & $574 \pm 7$ & $752 \pm 7$ & $887 \pm 48$ & $1043 \pm 2$ & - \\
\hline Anneal & 91.2 & 1283 & 110 & 450 & - & $831 \pm 15$ & $852 \pm 14$ & $1188 \pm 30$ & - \\
\hline Anneal & 72.0 & 1283 & 110 & 900 & $395 \pm 32$ & $581 \pm 16$ & $676 \pm 132$ & $1017 \pm 25$ & - \\
\hline Anneal & 95.7 & 1037 & 200 & - & - & $817 \pm 4$ & $876 \pm 61$ & $1015 \pm 17$ & - \\
\hline Anneal & 97.8 & 1037 & 200 & 700 & $481 \pm 102$ & $678 \pm 67$ & $484 \pm 102$ & $1067 \pm 57$ & - \\
\hline Anneal & 109.0 & 1109 & 300 & - & - & $810 \pm 5$ & $839 \pm 6$ & $1167 \pm 7$ & - \\
\hline Anneal & 105.3 & 1109 & 300 & 300 & $335 \pm 20$ & $557 \pm 144$ & $956 \pm 9$ & $1053 \pm 24$ & - \\
\hline Anneal & 105.4 & 1109 & 300 & 450 & $483 \pm 71$ & $680 \pm 44$ & $1046 \pm 56$ & $1197 \pm 17$ & - \\
\hline Anneal & 105.3 & 1109 & 300 & 700 & $475 \pm 32$ & $727 \pm 22$ & $859 \pm 288$ & $1173 \pm 47$ & - \\
\hline Anneal & 91.5 & 1109 & 300 & 900 & $318 \pm 53$ & $546 \pm 19$ & $895 \pm 27$ & $1030 \pm 42$ & - \\
\hline $\mathrm{SC} 1+\mathrm{HF}$ cleaning & 284.7 & 3000 & 300 & - & - & $650 \pm 46$ & $649 \pm 48$ & $649 \pm 48$ & Pass $(2 / 3)$ \\
\hline
\end{tabular}

early delamination of the coating. The second critical load, $\mathrm{L}_{\mathrm{CSi} 2}$, occurred at the beginning of the continuous cracking caused by the phase transformation of the silicon, as shown in Fig. 1(b). Continuous breakage means that the cracking of silicon continues until the end of the scratch. The residual scratch groove depth and OM is used to verify that the failure occurs. Usually, the first delamination of the coating occurs due to continuous breakage of the substrate as the coating

TABLE III. Critical load values with standard deviations for $\mathrm{TiO}_{2}$ coated systems with different coating thicknesses, deposition parameters, and postannealing temperatures. The RCA-cleaning was used prior to deposition.

\begin{tabular}{|c|c|c|c|c|c|c|c|c|c|}
\hline Series & $\begin{array}{c}\text { Thickness } \\
(\mathrm{nm})\end{array}$ & ALD cycles & $\begin{array}{c}\text { Growth T } \\
\left({ }^{\circ} \mathrm{C}\right)\end{array}$ & $\begin{array}{c}\text { Annealing } \mathrm{T} \\
\left({ }^{\circ} \mathrm{C}\right)\end{array}$ & $\begin{array}{l}\mathrm{L}_{\mathrm{CSi1}} \\
(\mathrm{mN})\end{array}$ & $\begin{array}{l}\mathrm{L}_{\mathrm{CSi} 2} \\
(\mathrm{mN})\end{array}$ & $\begin{array}{c}\mathrm{L}_{\text {CALD1 }} \\
(\mathrm{mN})\end{array}$ & $\begin{array}{c}\mathrm{L}_{\mathrm{CALD} 2} \\
(\mathrm{mN})\end{array}$ & Tape test \\
\hline Si (Ref. 1) & - & - & - & - & $493 \pm 81$ & $727 \pm 69$ & - & - & - \\
\hline Si (Ref. 3) & - & - & - & - & $505 \pm 24$ & $740 \pm 50$ & - & - & - \\
\hline Thickness & 21.1 & 531 & 300 & - & $682 \pm 7$ & $736 \pm 18$ & $860 \pm 98$ & $860 \pm 98$ & - \\
\hline Thickness & 45.5 & 1062 & 300 & - & $676 \pm 23$ & $752 \pm 11$ & $897 \pm 26$ & $915 \pm 46$ & - \\
\hline Thickness and temperature & 91.5 & 2124 & 300 & - & $484 \pm 76$ & $731 \pm 31$ & $890 \pm 16$ & $915 \pm 8$ & - \\
\hline Thickness & 323.5 & 6373 & 300 & - & $389 \pm 47$ & $597 \pm 31$ & $838 \pm 22$ & $911 \pm 17$ & - \\
\hline Temperature & 97.3 & 1924 & 110 & - & - & $868 \pm 3$ & $998 \pm 51$ & $1097 \pm 133$ & - \\
\hline Temperature & 102.5 & 2313 & 150 & - & $643 \pm 37$ & $721 \pm 11$ & $1016 \pm 35$ & $1080 \pm 84$ & - \\
\hline Temperature & 90.5 & 2467 & 200 & - & $626 \pm 91$ & $753 \pm 17$ & $987 \pm 22$ & $1001 \pm 15$ & - \\
\hline Temperature & 105.0 & 1953 & 250 & - & $391 \pm 13$ & $660 \pm 8$ & $654 \pm 9$ & $660 \pm 8$ & - \\
\hline Anneal & 101.0 & 1924 & 110 & - & - & $783 \pm 8$ & $990 \pm 17$ & $1084 \pm 39$ & - \\
\hline Anneal & 95.0 & 1924 & 110 & 300 & - & - & $50 \pm 0$ & $50 \pm 0$ & Fail (3/3) \\
\hline Anneal & 93.2 & 1924 & 110 & 450 & - & - & $50 \pm 0$ & $50 \pm 0$ & Fail $(3 / 3)$ \\
\hline Anneal & 97.5 & 2124 & 300 & - & $538 \pm 4$ & $820 \pm 7$ & $998 \pm 28$ & $1069 \pm 30$ & - \\
\hline Anneal & 97.5 & 2124 & 300 & 450 & $485 \pm 21$ & $735 \pm 100$ & $990 \pm 53$ & $1075 \pm 36$ & - \\
\hline \multirow[t]{2}{*}{ Anneal } & 93.0 & 2124 & 300 & 900 & $426 \pm 35$ & $636 \pm 17$ & $822 \pm 11$ & $928 \pm 39$ & - \\
\hline & 390.2 & 7614 & 200 & - & - & - & $165 \pm 18$ & $165 \pm 18$ & Pass (3/3) \\
\hline
\end{tabular}



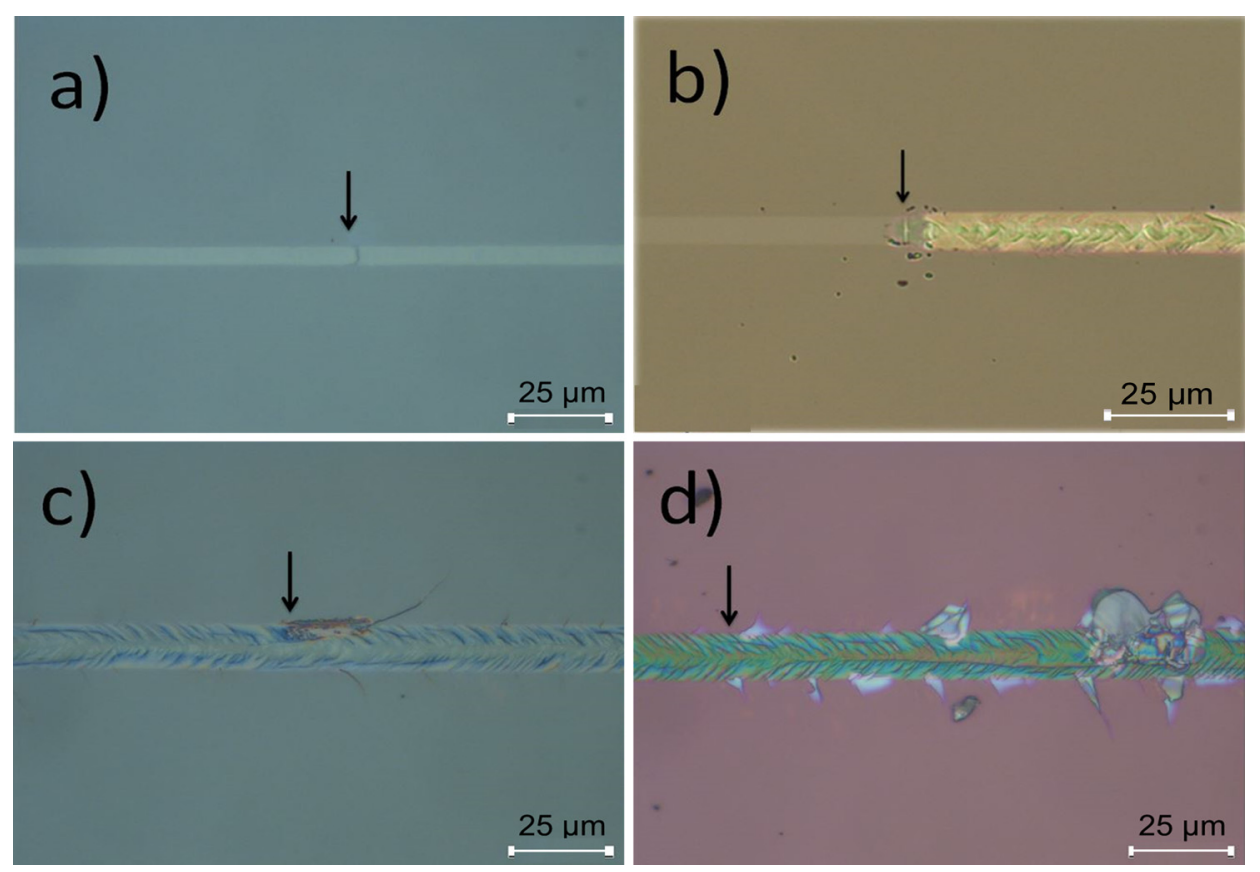

FIG. 1. (Color online) Critical loads explained: (a) $\mathrm{L}_{\mathrm{CSi1}}$ is the first observed local breakage point of the silicon substrate, (b) $\mathrm{L}_{\mathrm{CSi} 2}$ is the beginning of the continuous cracking of the silicon substrate, (c) $\mathrm{L}_{\mathrm{CALD} 1}$ is the first observed local delamination of the coating, and (d) $\mathrm{L}_{\mathrm{CALD} 2}$ is where the continuous delamination of the coating begins.

thus is forced to bend deeper due to the increasing load. The critical load $\mathrm{L}_{\mathrm{CALD1}}$ was the first observed local delamination point of the coating, as shown in Fig. 1(c). $\mathrm{L}_{\mathrm{CALD} 1}$ has the tendency of occurring right after $\mathrm{L}_{\mathrm{CSi} 2}$ and on the sides of the scratch channel. The critical load $\mathrm{L}_{\mathrm{CALD} 2}$ described the continuous delamination of the coating [see Fig. 1(d)]. In some coatings, $\mathrm{L}_{\mathrm{CALD} 2}$ was easy to notice as large parts of the coating delaminated. Usually, $\mathrm{L}_{\mathrm{CALD} 2}$ was observed when local delaminations occurred continuously.
By using determined critical loads, the adhesion properties are analyzed in a similar manner, as shown in Fig. 2. The visual comparison shows clear differences in adhesion between coating materials. The critical load values with standard deviations are presented for different coatings in Tables II-IV. The measurements have good repeatability as the standard deviation value of the measurements is rather small for each material. However, the behavior of the silicon substrate

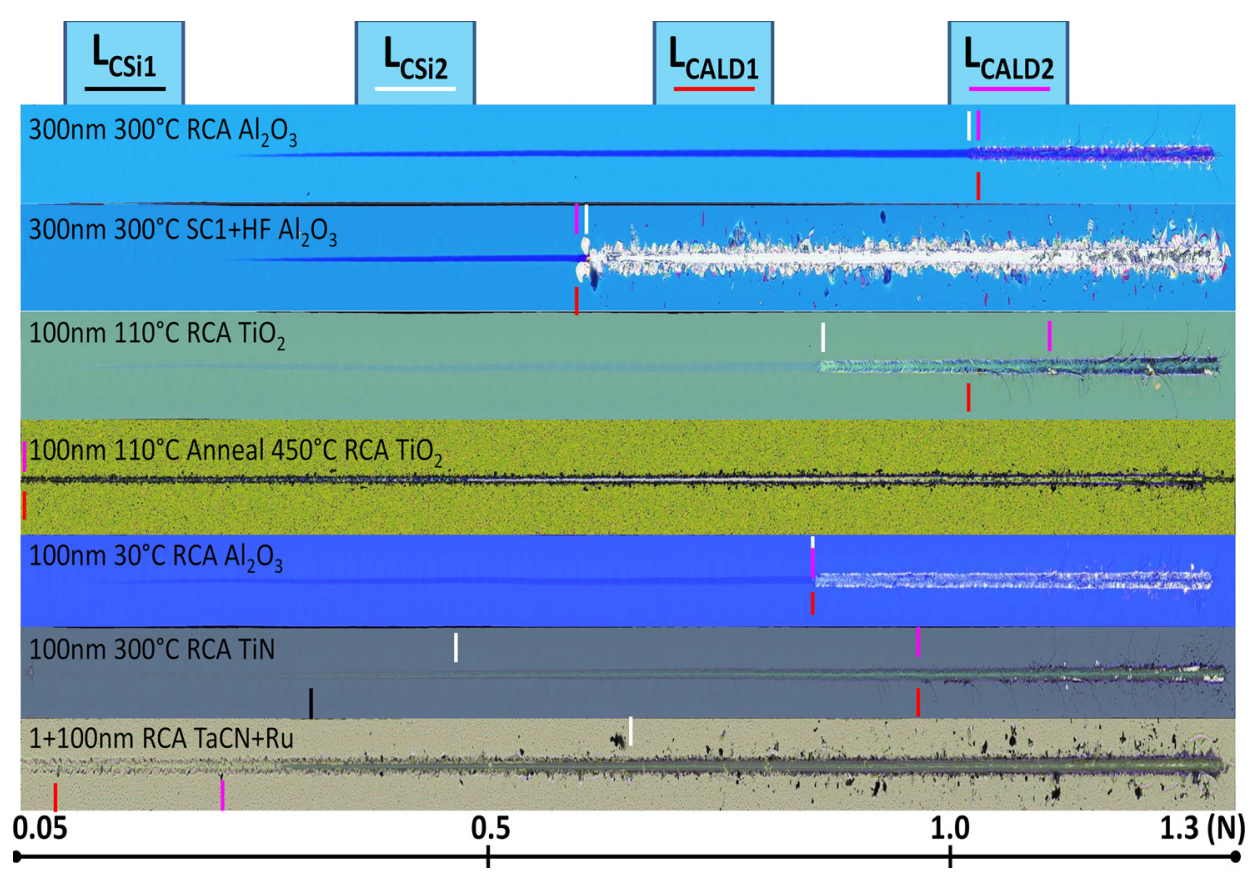

FIG. 2. (Color online) Visual comparison of critical load values for different coatings. Panorama images taken by the Micro-Combi tester showed clear variation in adhesion properties between different coatings and cleaning methods. 
TABLE IV. Critical load values with standard deviations for TiN and $\mathrm{TaCN}+\mathrm{Ru}$ coated systems with different coating thicknesses, deposition parameters, and postannealing temperatures. The RCA-cleaning was used prior to deposition.

\begin{tabular}{|c|c|c|c|c|c|c|c|}
\hline Series & Coating material & Thickness (nm) & Growth $\mathrm{T}\left({ }^{\circ} \mathrm{C}\right)$ & $\mathrm{L}_{\mathrm{CSi} 1}(\mathrm{mN})$ & $\mathrm{L}_{\mathrm{CSi} 2}(\mathrm{mN})$ & $\mathrm{L}_{\mathrm{CALD1}}(\mathrm{mN})$ & $\mathrm{L}_{\mathrm{CALD} 2}(\mathrm{mN})$ \\
\hline Si (Ref. 4) & - & - & - & $443 \pm 2$ & $690 \pm 2$ & - & - \\
\hline Thickness & $\mathrm{TiN}$ & 23.0 & 350 & $293 \pm 9$ & $577 \pm 28$ & $950 \pm 64$ & $1081 \pm 65$ \\
\hline Thickness & $\mathrm{TiN}$ & 59.5 & 350 & $246 \pm 3$ & $519 \pm 10$ & $671 \pm 113$ & $1081 \pm 52$ \\
\hline Thickness and temperature & $\mathrm{TiN}$ & $113 \pm 3$ & 350 & $277 \pm 39$ & $493 \pm 21$ & $1011 \pm 42$ & $1169 \pm 41$ \\
\hline Temperature & $\mathrm{TiN}$ & $113 \pm 3$ & 300 & $281 \pm 15$ & $468 \pm 17$ & $971 \pm 10$ & $1019 \pm 46$ \\
\hline Temperature & $\mathrm{TiN}$ & $90 \pm 3$ & 410 & $219 \pm 26$ & $515 \pm 24$ & $1046 \pm 9$ & $1143 \pm 34$ \\
\hline Si (Ref. 5) & - & - & - & $613 \pm 73$ & $724 \pm 37$ & - & - \\
\hline Thickness & $\mathrm{TaCN}+\mathrm{Ru}$ & $(1)+19.9$ & - & $528 \pm 60$ & $743 \pm 35$ & $743 \pm 35$ & $743 \pm 35$ \\
\hline Thickness & $\mathrm{TaCN}+\mathrm{Ru}$ & $(1)+47.7$ & - & - & $687 \pm 6$ & $85 \pm 22$ & $234 \pm 1$ \\
\hline Thickness & $\mathrm{TaCN}+\mathrm{Ru}$ & $(1)+100$ & - & - & $670 \pm 15$ & $106 \pm 53$ & $275 \pm 38$ \\
\hline
\end{tabular}

underneath the coating varied, which in some cases caused a large scatter.

\section{B. $\mathrm{Al}_{2} \mathrm{O}_{3}$ coating}

The influence of the deposition temperature and the coating thickness on the critical loads of ALD $\mathrm{Al}_{2} \mathrm{O}_{3}$ is presented in Figs. 3(a)-3(c) and Table II. The critical loads of the silicon substrate are presented as reference.

Adhesion was good for the films deposited at $50-110^{\circ} \mathrm{C}$ but not as good for the film deposited at $30^{\circ} \mathrm{C}$, as shown in Fig. 3(b). The critical load values for the $\mathrm{Al}_{2} \mathrm{O}_{3}$ films were on a similar level for all the coating thicknesses in Fig. 3(a). The thickest films, 300 and $600 \mathrm{~nm}$, gave the most stable performance during scratching. The critical load values of the silicon substrate, $\mathrm{L}_{\mathrm{CSi} 1}$ and $\mathrm{L}_{\mathrm{CSi} 2}$, were lower for the coating thicknesses in the range $20-100 \mathrm{~nm}$ compared to the values of uncoated silicon reference. However, for the coating thicknesses of 300 and $600 \mathrm{~nm}$, the critical load values for silicon were higher compared to uncoated silicon. This suggests that the thicker ALD $\mathrm{Al}_{2} \mathrm{O}_{3}$ film can improve the load carrying capacity of the silicon wafer.

The effect of the different cleaning procedures on the adhesion performance of $\mathrm{Al}_{2} \mathrm{O}_{3}$ film was clearly observed. The RCA cleaning normally used in this study provided higher critical load values compared to SC1+HF-cleaning. The $\mathrm{SC} 1+\mathrm{HF}$-cleaned $300 \mathrm{~nm}$ thick $\mathrm{Al}_{2} \mathrm{O}_{3}$ coating deposited at $300{ }^{\circ} \mathrm{C}$ had critical load values about $60 \%$ of the values received with $\mathrm{RCA}$ cleaned samples (see Table II).

The effect of annealing temperature on the film adhesion was of interest since the coatings undergo temperature cycling during the processing of, e.g., MEMS devices. The annealing experiments were therefore carried out at temperatures of $300,450,700$, and $900^{\circ} \mathrm{C}$, which are typical temperatures for electronics processing.

The critical loads for coating delamination of the annealed tests for $\mathrm{Al}_{2} \mathrm{O}_{3}$ coating are presented in Figs. 4(a)-4(c). It is noticeable in Fig. 4 that the critical load values, both silicon breakage and ALD delamination, for samples deposited at $110^{\circ} \mathrm{C}$ were lower after annealing treatments, especially for the coatings annealed at $900{ }^{\circ} \mathrm{C}$, which were crystallized and had increased tensile stress. According to XRR (and also $\mathrm{XRD}$, not reported in detail here), the $\mathrm{Al}_{2} \mathrm{O}_{3}$ remained amorphous up to $700{ }^{\circ} \mathrm{C}$ with a density of ca. $3.1 \mathrm{~g} / \mathrm{cm}^{2}$ and was crystalline after annealing at $900^{\circ} \mathrm{C}$ with a density of ca. $3.6 \mathrm{~g} / \mathrm{cm}^{2}$. The samples deposited at $300{ }^{\circ} \mathrm{C}$ were not affected as much with annealing, and their adhesion remained good although crystallization occurred and stress increased. The critical loads $\mathrm{L}_{\mathrm{CSi} 1}$ and $\mathrm{L}_{\mathrm{CSi} 2}$ for the silicon breaking tend to decrease with increased annealing temperature, and the beneficial effect of the coating for the silicon performance seems to be lost due to crystallization. The adhesion of the coating and the beneficial load carrying capacity suffer during the annealing process.

\section{C. $\mathrm{TiO}_{2}$ coating}

The critical loads of ALD $\mathrm{TiO}_{2}$ coatings are presented in Figs. 5 and 6. The adhesion between the silicon and $\mathrm{TiO}_{2}$ was good as the first observed delamination took place after the breakage point of silicon substrate. The only exception was $390 \mathrm{~nm}$ thick $\mathrm{ALD} \mathrm{TiO}_{2}$ deposited at $200{ }^{\circ} \mathrm{C}$ for which the coating delamination occurred at an early stage (with $\mathrm{L}_{\mathrm{CALD} 2}=165 \mathrm{mN}$ ) of the test (see Table III). This might occur due to high stress and very large (even over $500 \mathrm{~nm}$ ) crystals. $^{36}$

Good adhesion performance remained after annealing for the $\mathrm{TiO}_{2}$ coatings deposited in $300{ }^{\circ} \mathrm{C}$. Similar to $\mathrm{Al}_{2} \mathrm{O}_{3}$, the annealing treatment slightly lowered the adhesion values. However, in the two samples deposited at $110^{\circ} \mathrm{C}$, the adhesion failed as the delamination occurred instantly at the beginning of the scratch test.

\section{TiN coating}

The influence of deposition temperature and coating thickness on the critical loads of TiN are presented in Figs. 7(a) and 7(b). Overall, adhesion of TiN on Si substrate was good. The load carrying capacity of the silicon substrate, however, decreased slightly due to deposition as the $\mathrm{L}_{\mathrm{CSi} 2}$ was lower than the one of uncoated Si substrate.

\section{E. TaCN+Ru coating}

The impact of deposition temperature and coating thickness on the critical loads of $\mathrm{TaCN}+\mathrm{Ru}$ coating are presented in Fig. 8. Especially with increasing coating thickness, the 

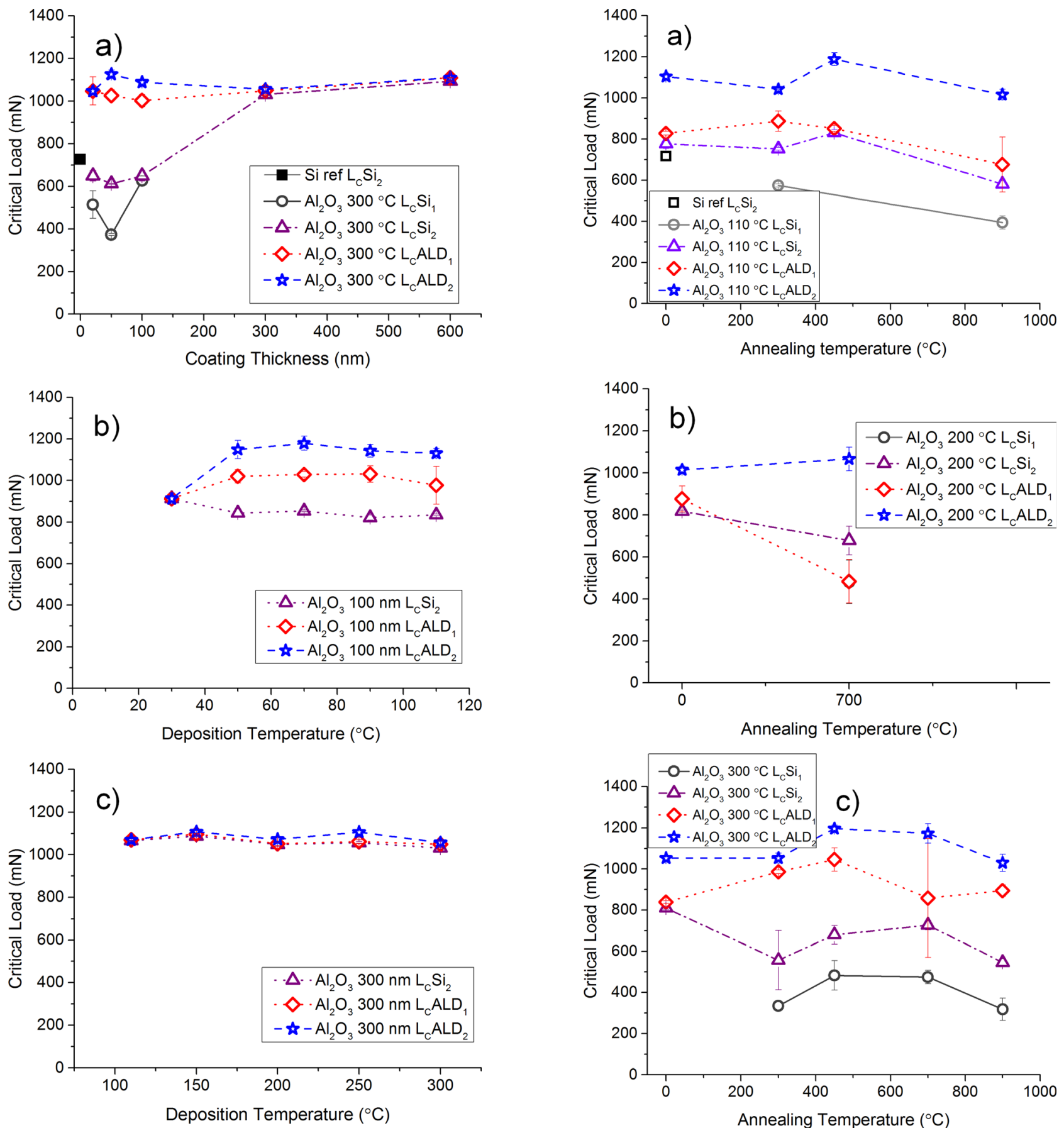

FIG. 3. (Color online) Critical load values for (a) $\mathrm{Al}_{2} \mathrm{O}_{3}$ films with different nominal coating thicknesses deposited at $300^{\circ} \mathrm{C}$, (b) $\mathrm{Al}_{2} \mathrm{O}_{3}(100 \mathrm{~nm})$ deposited in the range of $30-110^{\circ} \mathrm{C}$, and (c) $\mathrm{Al}_{2} \mathrm{O}_{3}(300 \mathrm{~nm})$ deposited in the range of $110-300^{\circ} \mathrm{C}$.

adhesion was poor, as $\mathrm{L}_{\mathrm{CALD} 2}$ occurs at a substantially lower load than $\mathrm{L}_{\mathrm{CSi} 2}$.

\section{F. Scotch tape testing}

The adhesion performance of the samples: RCA-cleaned $\mathrm{Al}_{2} \mathrm{O}_{3} \quad\left(300 \mathrm{~nm} 300^{\circ} \mathrm{C}\right), \quad \mathrm{SC} 1+\mathrm{HF}$ cleaned $\mathrm{Al}_{2} \mathrm{O}_{3}$ $\left(300 \mathrm{~nm} 300^{\circ} \mathrm{C}\right)$, RCA-cleaned $\mathrm{TiO}_{2}\left(390 \mathrm{~nm} 200^{\circ} \mathrm{C}\right)$, and RCA-cleaned $\mathrm{TiO}_{2}\left(100 \mathrm{~nm} 110^{\circ} \mathrm{C}\right)$ samples annealed at 300 and $450^{\circ} \mathrm{C}$ were evaluated also using Scotch tape testing.

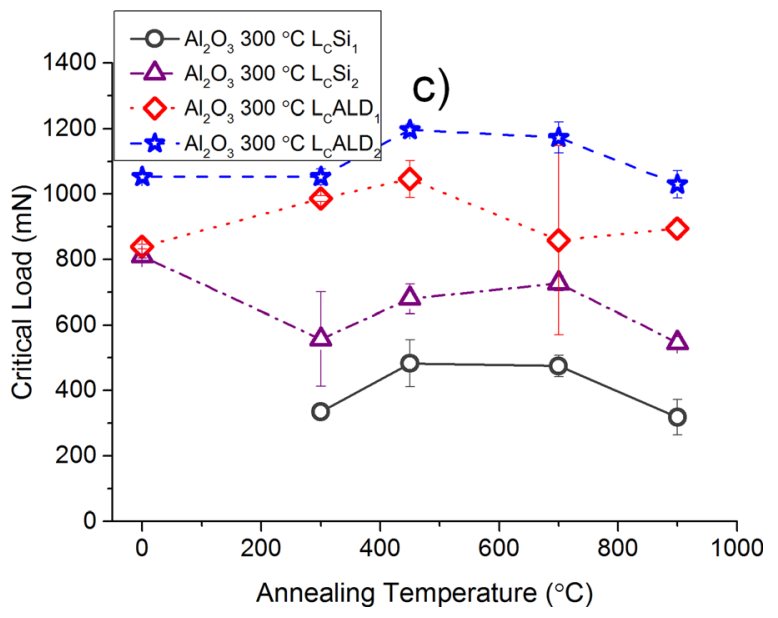

FIg. 4. (Color online) Critical load values for $\mathrm{Al}_{2} \mathrm{O}_{3}$ films (100 nm) (a) deposited at $110^{\circ} \mathrm{C}$ and annealed in the temperature range of $300-900{ }^{\circ} \mathrm{C}$, (b) deposited at $200^{\circ} \mathrm{C}$ and annealed at $700^{\circ} \mathrm{C}$, and (c) deposited at $300^{\circ} \mathrm{C}$ and annealed in the temperature range of $300-900^{\circ} \mathrm{C}$.

The results are presented in Tables II-IV. The RCA-cleaned nonannealed $\mathrm{Al}_{2} \mathrm{O}_{3}$ and $\mathrm{TiO}_{2}$ samples passed all three tests, and the coating was still adhered on the Si substrate after the rapid tape removal from the top of the coating. $\mathrm{SC} 1+\mathrm{HF}-$ cleaned $\mathrm{Al}_{2} \mathrm{O}_{3}$ passed the test two times out of three. The annealed $\mathrm{TiO}_{2}$ samples failed all three tests as the coating was removed from the tested area. In Fig. 9, for the $\mathrm{TiO}_{2}$ sample deposited at $110^{\circ} \mathrm{C}$ and annealed at $450^{\circ} \mathrm{C}$, the adhesion failed. The coating areas, where the tape had a contact, 

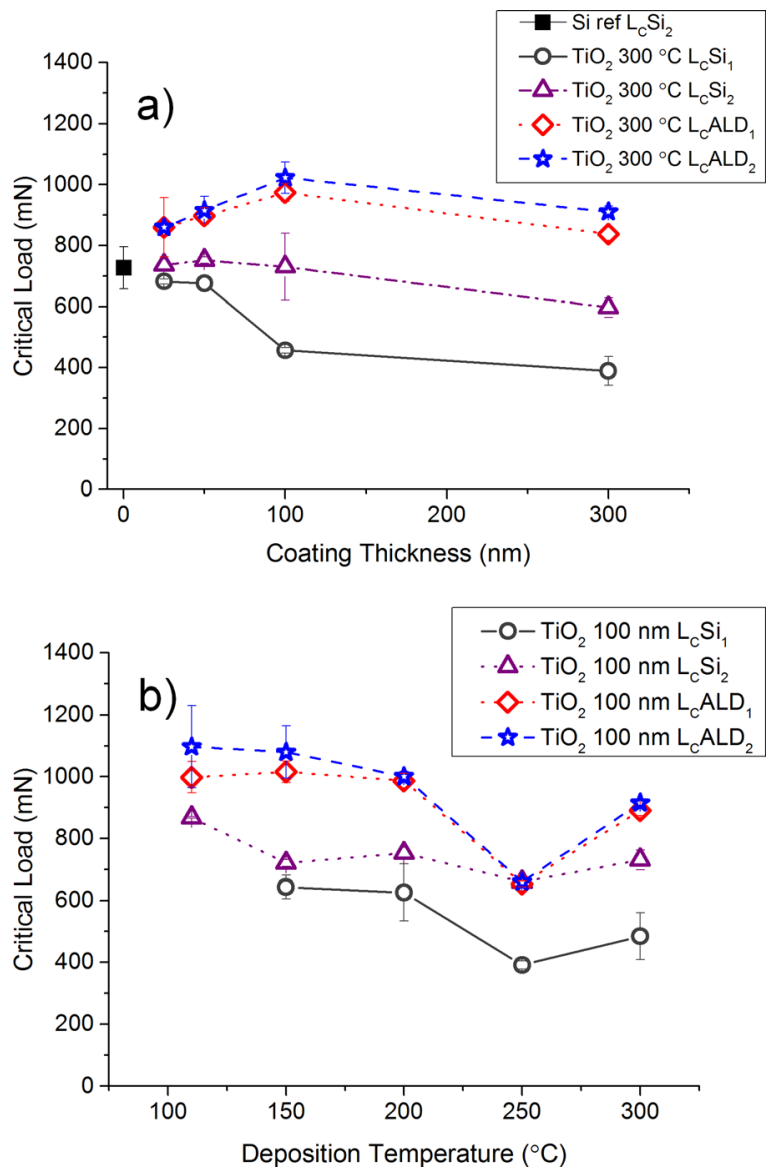

FIG. 5. (Color online) Critical load values for $\mathrm{TiO}_{2}$ coatings with (a) nominal thickness in the range of $20-300 \mathrm{~nm}$ deposited at $300^{\circ} \mathrm{C}$, and (b) thickness of $100 \mathrm{~nm}$ deposited in the temperature range of $110-300^{\circ} \mathrm{C}$.

were peeled off, whereas the coating still existed on other areas of the substrate.

The comparison of Scotch tape test results with scratch testing gave interesting observations. The annealed $\mathrm{TiO}_{2}\left(\mathrm{~L}_{\mathrm{CALD} 1}\right.$ $\ll \mathrm{L}_{\mathrm{CSi} 2}$ ) had the poorest adhesion properties in the scratch test since the coating delamination occurred immediately at the beginning of the scratch. In the tape test, the coating was removed completely from the silicon substrate, as shown in Fig. 9. Also, the cohesion of the coating failed as well. However, a coating with a slightly better adhesion could already pass the Scotch tape test, as was the case with RCA-cleaned $\mathrm{TiO}_{2}(390 \mathrm{~nm}$ $\left.200{ }^{\circ} \mathrm{C}\right)\left(\mathrm{L}_{\mathrm{CALD} 1}<\mathrm{L}_{\mathrm{CSi} 2}\right)$. For this coating, the delamination occurred well before the breakage point of the Si substrate in the scratch test and thus had significantly poorer adhesion than most of the coatings investigated in this work. Yet, it survived the Scotch tape test. However, the SC1+HF-cleaned $\mathrm{Al}_{2} \mathrm{O}_{3}$ $\left(\mathrm{L}_{\mathrm{CALD1} 1}=\mathrm{L}_{\mathrm{CSi} 2}\right)$ coating only passed two tests out of three, which shows that Scotch-tape tests are not consistent. The RCA-cleaned $\mathrm{Al}_{2} \mathrm{O}_{3}\left(\mathrm{~L}_{\mathrm{CALD1}}>\mathrm{L}_{\mathrm{CSi} 2}\right)$ coating survived the Scotch-tape test without problems, as expected.

\section{DISCUSSION}

\section{A. Comparison of adhesion testing for ALD films}

The new critical load criteria were introduced for scratch adhesion testing; this is helpful in comparing a wide
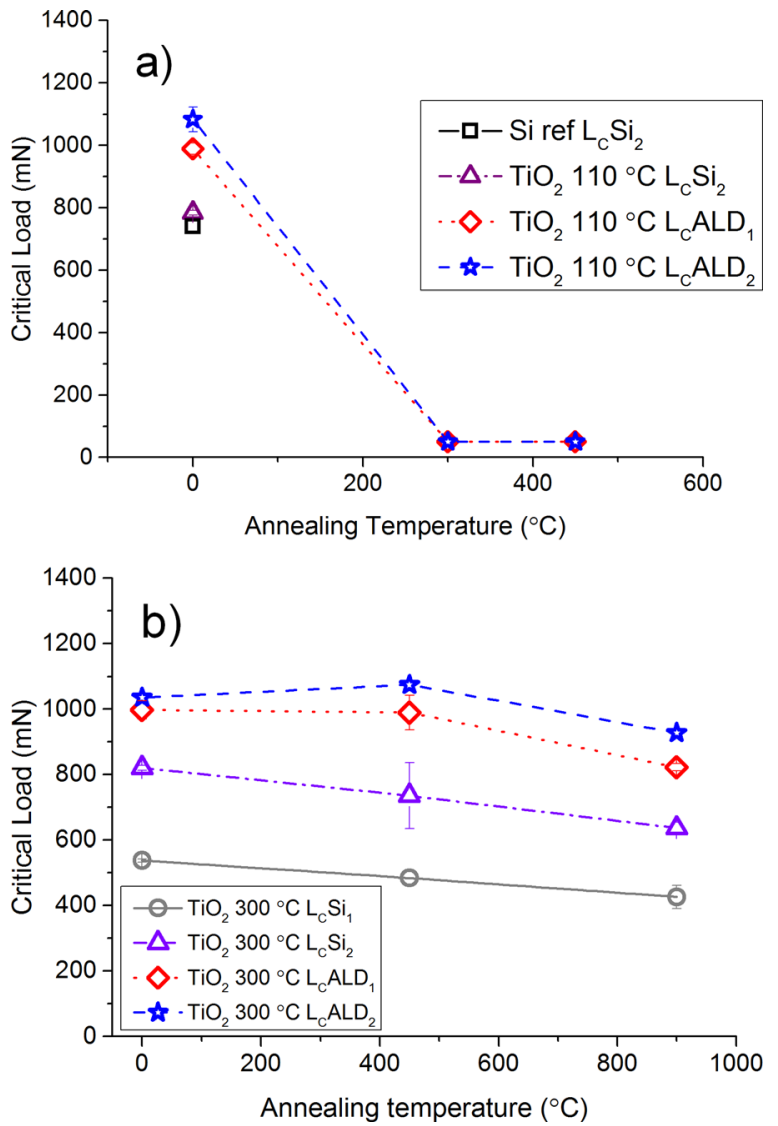

FIG. 6. (Color online) Critical load values for $\mathrm{TiO}_{2}$ coatings with (a) the thickness of $100 \mathrm{~nm}$ deposited at $110^{\circ} \mathrm{C}$ annealed at temperatures 300 and $450{ }^{\circ} \mathrm{C}$, and (b) the thickness of $100 \mathrm{~nm}$ deposited at $300^{\circ} \mathrm{C}$ and annealed at 450 and $900^{\circ} \mathrm{C}$.

selection of coating materials. Introduced critical load criteria provide an accurate mean to evaluate adhesion properties of thin coatings when compared to the generally used Scotch tape test, which provides the information whether the adhesion is very poor or less poor. This was confirmed in the experiments carried out; only coatings with drastic adhesion problems failed the Scotch tape test and some with poor adhesion managed to pass. The scratch adhesion load criteria, on the other hand, provide numerical data of the critical values as well as the knowledge whether the adhesion failure occurs before or after the substrate breakage point.

In order to make an accurate comparison of the adhesion properties between the different coatings, however, one needs to use the same test parameters. In literature, there are articles, such as Beake et al., ${ }^{22}$ Wang et al., ${ }^{23}$ and Homola et al., ${ }^{37}$ about scratch testing of ALD films. However, only Ding et $a .^{20}$ had evaluated the adhesion properties of the ALD films. Ding had used adhesion energy values to explain the adhesion properties of ALD coatings.

One can debate about the critical load values obtained after the silicon substrate breakage point $\left(\mathrm{L}_{\mathrm{CSi} 2}\right)$. Certainly, the values obtained prior to the force of $\mathrm{L}_{\mathrm{CSi} 2}$ are more relevant to real-life applications, and thus, they are most relevant when comparing adhesion values. If the coating delamination did not occur prior to $\mathrm{L}_{\mathrm{CSi} 2}$, one might be interested to check how close to $\mathrm{L}_{\mathrm{CSi} 2}$ the first 

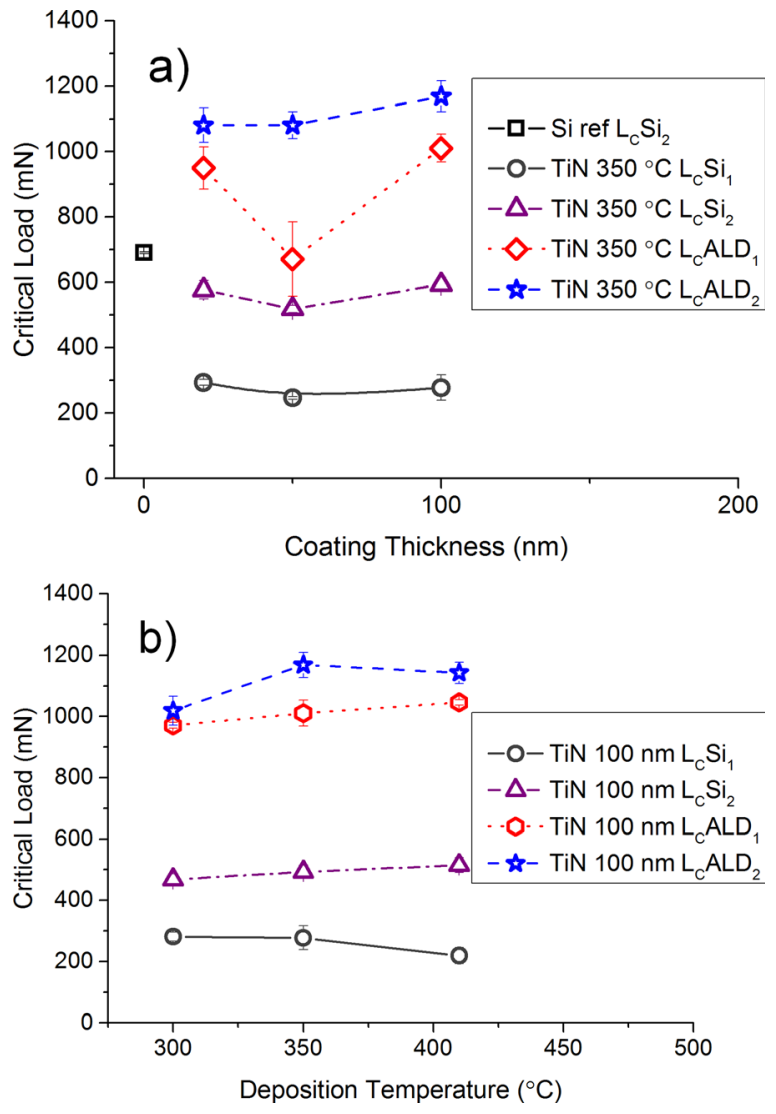

FIG. 7. (Color online) Critical load values for (a) TiN with nominal thickness values in the range of $20-100 \mathrm{~nm}$ deposited at $350^{\circ} \mathrm{C}$, and (b) TiN $(100 \mathrm{~nm}$ thick) deposited in the range of $300-410^{\circ} \mathrm{C}$.

delamination occurred. Although the cracking of silicon substrate beneath the coating makes quite an impact on the critical load values obtained after the force of $\mathrm{L}_{\mathrm{CSi} 2}$, the coatings with $\mathrm{L}_{\mathrm{CALD} 1}$ and $\mathrm{L}_{\mathrm{CALD} 2}$ occurring after $\mathrm{L}_{\mathrm{CSi} 2}$ have good adhesion. In the future, ALD coatings with good adhesion could, hopefully, be deposited on other substrates, e.g., steel or polymer, to further adjust the critical load values described in this paper.

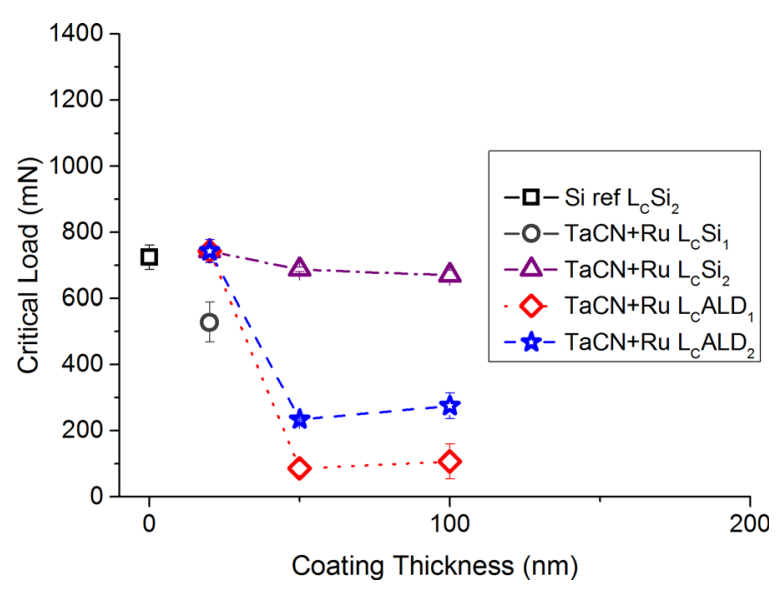

FIG. 8. (Color online) Critical load values for $\mathrm{TaCN}+\mathrm{Ru}$ coating with nominal thickness in the range of $20-100 \mathrm{~nm}$ series deposited at $300^{\circ} \mathrm{C}$.

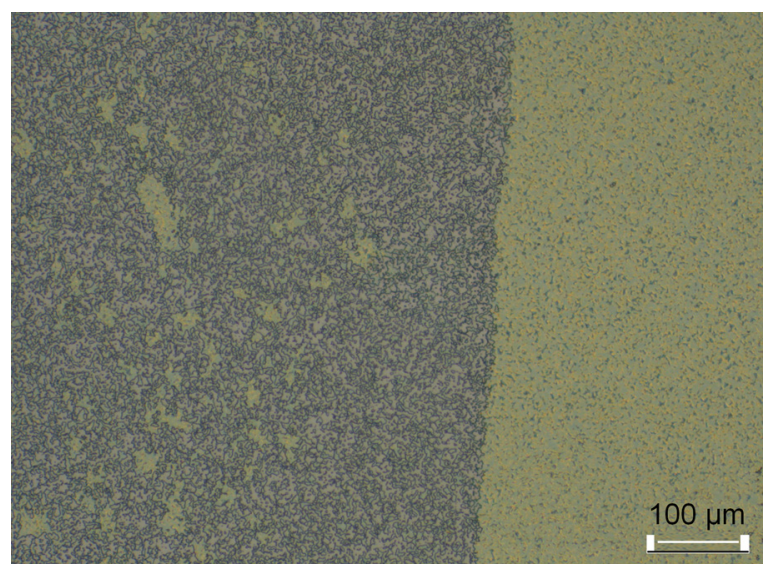

FIG. 9. (Color online) Sample $\mathrm{TiO}_{2}$ with the nominal thickness of $100 \mathrm{~nm}$ and deposition temperature $110^{\circ} \mathrm{C}$ with postannealing in $450^{\circ} \mathrm{C}$ did not pass the tape test. The tested area is on the left side, and the untouched surface is on the right side of the image.

\section{B. Adhesion and load carrying capacity}

In most cases, the adhesion performance between the ALD coatings and the Si substrate was good. There were, however, some exceptions due to pretreatments and annealing processes. A visual critical load comparison was shown in Fig. 2. Most of the samples cleaned with the full RCA sequence prior to the deposition process delaminated after the breakage point of silicon substrate. On the other hand, the SC1+HF-cleaned $\mathrm{Al}_{2} \mathrm{O}_{3}$ sample had poorer adhesion performance as the coating delaminated just before the substrate breakage point unlike a similar sample with RCA-clean, in which the coating delamination occurred with significantly higher load. The SC1+HFcleaning was used by Ding et al. ${ }^{20}$ in their study. Our result shows that the full RCA-cleaning allows better adhesion on the Si substrate than SC1+HF-cleaning.

Overall as deposited RCA-cleaned ALD $\mathrm{Al}_{2} \mathrm{O}_{3}$ and $\mathrm{TiO}_{2}$ coatings have good adhesion performance on $\mathrm{Si}$ substrate as the coating delamination occurs only after the breakage point of silicon substrate. ALD $\mathrm{Al}_{2} \mathrm{O}_{3}$ has slightly better adhesion properties compared to ALD $\mathrm{TiO}_{2}$ on silicon. For all the coatings deposited at lower temperatures, slightly better adhesion properties were measured. The annealing treatment caused the critical loads to drop for $\mathrm{Al}_{2} \mathrm{O}_{3}$ and $\mathrm{TiO}_{2}$ coatings, even drastically in the case of $\mathrm{TiO}_{2}$ deposited at $110^{\circ} \mathrm{C}$. Adhesion energy values were not calculated in this study due to the $\mathrm{Si}$ substrate breakage before the coating delamination, thus having a great effect on the delamination values.

Other ALD materials, namely, $\mathrm{TiN}$ and $\mathrm{TaCN}+\mathrm{Ru}$, were also investigated in this work. The adhesion of the TiN coating on silicon was good. The $\mathrm{TaCN}+\mathrm{Ru}$ coating had adequate adhesion properties with the $20 \mathrm{~nm}$ thick sample as adhesion failed at the same moment as the Si substrate broke beneath. With the thicker $\mathrm{TaCN}+\mathrm{Ru}$-coatings, however, the adhesion performance was poor as the critical load for continuous delamination, $\mathrm{L}_{\mathrm{CALD} 2}$, occurred well before the continuous breakage point of the $\mathrm{Si}$ substrate, $\mathrm{L}_{\mathrm{CSi} 2}$.

The results suggest that thick $\mathrm{Al}_{2} \mathrm{O}_{3}$ coating helps the underlying substrate to tolerate higher contact load. This load carrying capacity increased as the coating got thicker. 
The difference in the critical load for the Si substrate breakage with and without one of these coatings with $300 \mathrm{~nm}$ was rather significant: $\mathrm{L}_{\mathrm{CSi} 2}$ for plain $\mathrm{Si}$ was around $700 \mathrm{mN}$, whereas for $\mathrm{Al}_{2} \mathrm{O}_{3}$ coated $\mathrm{Si}$, it was close to $1100 \mathrm{mN}$. This behavior is beneficial for some $\mathrm{Si}$ based systems to provide better endurance in the application combined with the adhesion benefit as well.

In the case of TiN and thin $\mathrm{Al}_{2} \mathrm{O}_{3}$, the load carrying capacity of the silicon substrate, however, decreased slightly due to deposition as the $\mathrm{L}_{\mathrm{CSi} 2}$ of the coated system is lower than that of uncoated $\mathrm{Si}$. The reason for this is likely the high stresses occurring on the surface of the coating system due to deposition. Possibly for the same reason the adhesion of the $\mathrm{TaCN}+\mathrm{Ru}$ coating shows poor results, especially with increasing thickness. The high stress may be the reason for the sudden adhesion failure occurring to the annealed $\mathrm{TiO}_{2}$ coating deposited at $110^{\circ} \mathrm{C}$, causing spontaneous delamination. The change of temperature from $110^{\circ} \mathrm{C}$ to over $300^{\circ} \mathrm{C}$ causes the crystal structure of $\mathrm{TiO}_{2}$ to change from amorphous to crystalline, and, thus, increases the stress in the coating during the annealing process.

\section{CONCLUSIONS}

The scratch test method is widely used for adhesion evaluation of thin films and coatings. The results presented here suggested that the Scotch tape test does not provide enough information about the adhesion performance between the coating and the substrate, especially for the more demanding applications. However, the critical loads described in the standard on scratch testing were not directly applicable for ALD films. In this study, the bases for critical load evaluation by scratch testing were established, and the critical loads suitable for the ALD coating adhesion evaluation were determined as $\mathrm{L}_{\mathrm{CSi} 1}, \mathrm{~L}_{\mathrm{CSi} 2}, \mathrm{~L}_{\mathrm{CALD} 1}$, and $\mathrm{L}_{\mathrm{CALD} 2}$, representing the failure points of the silicon substrate and the coating delamination points of the ALD coating. This approach was suggested for adhesion evaluation of the ALD layers on silicon.

The adhesion performance of the $\mathrm{ALD} \mathrm{Al}_{2} \mathrm{O}_{3}, \mathrm{TiO}_{2}, \mathrm{TiN}$, and $\mathrm{TaCN}+\mathrm{Ru}$ coatings with thicknesses ranging between 20 and $600 \mathrm{~nm}$ and deposition temperature between 30 and $410^{\circ} \mathrm{C}$ on silicon wafers was investigated. In addition, the impact of the annealing process after deposition on adhesion was evaluated. The test results carried out using the scratch test showed that the coating deposition and annealing temperature, the thickness of the coating, and the surface pretreatments of the Si wafer all had an impact on the adhesion performance of the ALD coatings on the silicon wafer. Coating delamination occurred shortly after the breakage point of silicon in most cases. The best adhesion performance was measured for $\mathrm{Al}_{2} \mathrm{O}_{3}$ coatings on silicon. The adhesion between the ALD coatings and silicon substrate was generally good. The adhesion properties became slightly poorer after annealing the coatings at elevated temperatures. The coatings deposited on RCA-cleaned samples had better adhesion compared to the SC1+HF-cleaned sample. There was also improved load carrying capacity due to the coating thickness and deposition temperature, especially in the case of the ALD
$\mathrm{Al}_{2} \mathrm{O}_{3}$. The results show that the scratch test is a useful and applicable tool for adhesion evaluation of the ALD deposited coatings, even done for the thin $(20 \mathrm{~nm})$ coatings.

\section{ACKNOWLEDGMENTS}

The authors are grateful for Tekes and private funding by ASM Microchemistry Oy, Beneq Oy, Murata Electronics Oy, Picosun Oy, Okmetic Oyj, and Oxford Instruments Analytical Oy through the MECHALD Project. Special thanks also to Saima Ali and Timo Sajavaara for their contribution concerning XRR and low temperature ALD $\mathrm{Al}_{2} \mathrm{O}_{3}$ coating manufacturing, respectively. This work is linked to the Finnish Centers of Excellence in Atomic Layer Deposition (ref. 251220).

${ }^{1}$ R. L. Puurunen, J. Appl. Phys. 97, 121301 (2005).

${ }^{2}$ M. Ritala and M. Leskelä, Handbook of Thin Film Materials, edited by H. S. Nalwa (Academic, San Diego, CA, 2001), Vol. 1, pp. 103-159.

${ }^{3}$ S. M. George, Chem. Rev. 110, 111 (2009).

${ }^{4}$ F. Buja, G. Fiorentino, J. Kokorian, and W. M. Spengen, Nanotechnology 26, 255701 (2015).

${ }^{5}$ R. L. Puurunen, H. Kattelus, and T. Suntola, Handbook of Silicon Based MEMs Materials and Technologies, edited by V. Lindroos, M. Tilli, A. Lehto, and T. Motooka (Elsevier, Oxford, 2010), pp. 433-446.

${ }^{6}$ F. Gao, S. Arpiainen, and R. L. Puurunen, J. Vac. Sci. Technol. A 33, 010601 (2015).

${ }^{7}$ T. M. Mayer, J. W. Elam, S. M. George, P. G. Kotula, and R. S. Goeke, Appl. Phys. Lett. 82, 2883 (2003).

${ }^{8}$ N. D. Hoivik, J. W. Elam, R. J. Linderman, V. M. Bright, S. M. George, and Y. C. Lee, Sens. Actuators A 103, 100 (2003).

${ }^{9}$ C. F. Herrmann, F. W. DelRio, D. C. Miller, S. M. George, V. M. Bright, J. L. Ebel, R. E. Strawser, R. Cortez, and K. D. Leedy, Sens. Actuators A 135, 262 (2007).

${ }^{10}$ T. W. Scharf, S. V. Prasad, T. M. Mayer, R. S. Goeke, and M. T. Dugger, J. Mater. Res. 19, 3443 (2004).

${ }^{11}$ J. Kyynäräinen et al., Sens. Lett. 5, 126 (2007).

${ }^{12}$ R. L. Puurunen, J. Saarilahti, and H. Kattelus, ECS Trans. 11, 3 (2007).

${ }^{13}$ M. Blomberg, H. Kattelus, and A. Miranto, Sens. Actuators A 162, 184 (2010).

${ }^{14}$ A. Rissanen, U. Kantojärvi, M. Blomberg, J. Antila, and S. Eränen, Sens. Actuators A 182, 130 (2012).

${ }^{15}$ R. L. Puurunen et al., Sens. Actuators A 188, 240 (2012).

${ }^{16}$ B. D. Davidson, D. Seghete, S. M. George, and V. M. Bright, Sens. Actuators A 166, 269 (2011).

${ }^{17}$ S. T. Gonczy and N. Randall, Int. J. Appl. Ceram. Technol. 2, 422 (2005).

${ }^{18}$ K. L. Mittal, Electrocomponent Sci. Technol. 3, 21 (1976).

${ }^{19} \mathrm{~J}$. Meneve et al., Adhesion Measurement of Films and Coatings, edited by K. L. Mittal (VSP BV, The Netherlands, 2001), Vol. 2, pp. 79-106.

${ }^{20}$ J. N. Ding, X. F. Wang, N. Y. Yuan, C. L. Li, Y. Y. Zhu, and B. Kan, Surf. Coat. Technol. 205, 2846 (2011).

${ }^{21}$ O. M. E. Ylivaara et al., Thin Solid Films 552, 124 (2014).

${ }^{22}$ B. D. Beake, M. I. Davies, T. W. Liskiewicz, V. M. Vishnyakov, and S. R. Goodes, Wear 301, 575 (2013).

${ }^{23}$ W. K. Wang, H. C. Wen, C. H. Cheng, W. C. Chou, W. H. Yau, C. H. Hung, and C. P. Chou, J. Phys. Chem. Solids 75, 334 (2014).

${ }^{24}$ S. J. Bull, Tribol. Int. 30, 491 (1997).

${ }^{25}$ Y. Xie and H. M. Hawthorne, Surf. Coat. Technol. 155, 121 (2002).

${ }^{26}$ S. J. Bull and E. G. Berasetegui, Tribol. Int. 39, 99 (2006).

${ }^{27}$ W. Kern, Handbook of Semiconductor Wafer Cleaning Technology Science, Technology, and Applications, edited by W. Kern (William Andrew/Noyes, Westwood, NJ, 1993), pp. 1-67.

${ }^{28}$ B. Vermang, H. Goverde, A. Uruena, A. Lorenz, E. Cornagliotti, A. Rothschild, J. John, J. Poortmans, and R. Mertens, Sol. Energy Mater Sol. Cells 101, 204 (2012).

${ }^{29}$ R. L. Puurunen, J. Kiihamäki, and H. Kattelus, "Controlling the solubility of ALD aluminium oxide in deionised water," Poster presented at the AVS ALD 2005 Conference (2005).

${ }^{30}$ K. N. Stoev and K. Sakurai, Spectrochim. Acta B 54, 41 (1999). 
${ }^{31}$ S. Sintonen, A. Saima, O. M. E. Ylivaara, R. L. Puurunen, and H. Lipsanen, J. Vac. Sci. Technol. A 32, 01 A111 (2014).

${ }^{32}$ L. G. Parratt, Phys. Rev. 95, 359 (1954).

${ }^{33} \mathrm{C} 1624-05$, Standard Test Method for Adhesion Strength and Mechanical Failure Modes of Ceramic Coatings by Quantitative Single Point Scratch Testing (West Conshohocken, PA, 2015), p. 28.

${ }^{34}$ G. M. Pharr, W. C. Oliver, and D. S. Harding, J. Mater. Res. 6, 1129 (1991).
${ }^{35}$ V. Domnich and Y. Gogotsi, Rev. Adv. Mater. Sci. 3, 1 (2002).

${ }^{36}$ R. L. Puurunen, T. Sajavaara, E. Santala, V. Miikkulainen, T. Saukkonen, M. Laitinen, and M. Leskelä, J. Nanosci. Nanotechnol. 11, 8101 (2011).

${ }^{37}$ T. Homola, V. Buršíková, T. V. Ivanova, P. Souček, P. S. Maydannik, D. C. Cameron, and J. M. Lackner, "Mechanical properties of atomic layer deposited $\mathrm{Al}_{2} \mathrm{O}_{3} / \mathrm{ZnO}$ nanolaminates," Surf. Coat. Technol. (in press). 